\title{
Cerai Gugat: Telaah Penyebab Perceraian Pada Keluarga di Indonesia
}

\author{
Nibras Syafriani Manna ${ }^{1}$, Shinta Doriza ${ }^{1}$, Maya Oktaviani ${ }^{1}$ \\ ${ }^{1}$ Program studi Pendidikan Kesejahteraan Keluarga, Fakultas Teknik, Universitas Negeri Jakarta, \\ J1. Rawamangun Muka Raya, RT.11/RW. 14, Rawamangun, Pulogadung, Jakarta Timur, 13220 \\ Penulis untuk Korespondensi/E-mail: syafrianibras@gmail.com
}

\begin{abstract}
Data from the Religious Courts States (BADILAG) that divorce in Indonesia is increasing every year. The average divorce is dominated by divorce suits. These cases are interesting for research. The research method uses descriptive qualitative research methods. Collecting data techniques are based on literature studies and in-depth interviews with wives who conduct divorce claims. The results of the literature study on divorce include economic factors, poor communications factors, factors in the presence of a third person or infidelity, as well as social and cultural factors. The results of in-depth interviews show that couples who want to get married consider premarital education only limited to the formality of the process of carrying out marriage and the average divorced couple acknowledges that the lack of awareness of the meaning of marriage.
\end{abstract}

Abstrak - Data Badan Peradilan Agama (BADILAG) menyatakan bahwa perceraian di Indonesia setiap tahunnya selalu meningkat. Rata-rata perceraian didominasi oleh cerai gugat. Hal ini menarik perhatian untuk diteliti. Metode penelitian menggunakan kualitatif deskriptif. Teknik pengumpulan data berdasarkan studi literatur dan wawancara mendalam pada istri yang melakukan gugat cerai. Hasil studi literatur tentang perceraian di Indonesia terlihat bahwa penyebab perceraian antara lain faktor ekonomi, faktor komunikasi yang buruk, faktor adanya orang ketiga atau perselingkuhan, serta faktor sosial dan budaya. Hasil wawancara mendalam menunjukan bahwa pasangan yang ingin menikah menganggap pendidikan pra-nikah hanya sebatas formalitas proses untuk melaksanakan pernikahan serta rata-rata pasangan yang sudah bercerai mengakui bahwa minimnya kesadaran terhadap makna pernikahan.

Keywords - Divorce lawsuit, Factors of Divorce, Literature Study.

\section{PENDAHULUAN}

$\mathrm{M}$ anusia telah memiliki naluri untuk melakukan interaksi dengan sesamanya semenjak dilahirkan ke dunia. Interaksi hadir dalam kehidupan manusia sebagai sesuatu yang vital. Dalam interaksi sosial terdapat hubungan timbal balik antara dua orang atau lebih, dan masing-masing orang yang terlibat di dalamnya yang memainkan peran secara aktif. Interaksi sosial juga lebih dari sekedar terjadinya hubungan antara pihak-pihak yang terlibat melainkan terjadi proses saling mempengaruhi [1].

Proses sosial adalah cara-cara berhubungan yang terlihat apabila orang perorang dan kelompok- kelompok sosial saling bertemu dan menentukan sistem serta bentuk-bentuk hubungan tersebut. Salah satu bentuk dari proses sosial yang di dalamnya terdapat interaksi sosial adalah perkawinan. Setiap manusia yang hidup bersama terikat perkawinan pasti mendambakan agar keluarga yang mereka bina dapat berjalan harmonis dan selalu diberkahi Tuhan [1]. Pasangan yang tidak menjalankan perannya dalam rumah tangga, tidak akan mencapai tujuan perkawinannya. Tujuan rumah tangga menjadi bias atau berkemungkinan dalam proses menuju tujuan perkawinan, rumah tangga tersebut tidak mampu menciptakan kebahagiaan, sehingga sebuah perkawinan berujung dengan perceraian. 
Setiap rumah tangga memiliki kondisi idealnya masing-masing yang mengarah pada keharmonisan. Keharmonisan dapat terwujud dengan adanya komunikasi asosiatif. Komunikasi asosiatif sendiri merupakan komunikasi positif, menciptakan keteraturan dalam kelompok sosial yang anggotanya dalam keadaan harmoni sehingga menciptakan polapola kerja sama [2]. Artinya, komunikasi ini mengandung kerjasama yang didalamnya terdapat proses masuk dan diterimanya suatu pemahaman. Adapula akomodasi dimana kita akan saling bertoleransi membangun sebuah kompromi. Akomodasi adalah bagaimana para pelaku dan rekannya mampu berkomunikasi sehingga dapat menyesuaikan diri untuk mencapai kesepahaman [3]. Prilaku komunikasi akomodasi dapat tercermin saat pasangan mengatur keuangan ekonomi keluarga, menentukan tugas dan tanggung jawab dalam mengurus rumah tangga. Artinya. ketika pasangan menjalani perkawinan dan mengalami akulturasi atau penerimaan kebudayaan dari pasangannya menciptakan kesepakatan di rumah tangga. Hal demikian yang dapat mencapai komunikasi asosiatif dalam rumah tangga.

Ketidak tercapainya komunikasi asosiatif, maka pasangan tersebut akan mengalami komunikasi disosiatif. Komunikasi ini akan menimbulkan gejala-gejala abnormal atau gejala-gejala bersifat patologis sehingga masyarakat atau keluarga atau pasangan mengalami ketidakteraturan sosial. Gejala tersebut dinamakan masalah sosial. Salah satu masalah sosial adalah perceraian.

Perceraian merupakan upaya untuk melepaskan ikatan suami dan istri dari suatu perkawinan yang disebabkan oleh alasan tertentu. Perceraian terjadi karena sudah tidak adanya jalan keluar (dissolution marriage). Berdasarkan data perceraian dari Pengadilan Agama Kota Depok, pada tahun 2018 terdapat 271 kasus perceraian pada usia 2 tahun perkawinan. Adapun usia pasangan yang bercerai yaitu 23-37 tahun. Angka perceraian pada kasus ini mengalahkan perceraian pada usia 5 tahun perkawinan yang sebanyak 255 kasus, dan pada usia 10 tahun perkawinan sebanyak 134 kasus.

Menurut data dari Badan Peradilan Agama Mahkamah Agung, perceraian pada tahun 2010 sebanyak 285.184 kasus. Meningkat $17 \%$ pada tahun 2011 menjadi 333.368 kasus. Pada tahun 2012, angka perceraian meningkat kembali sebanyak 371.343 kasus. Pada tahun 2013 angka perceraian naik 9\% menjadi 406.099 kasus. Tahun 2014 jumlah kasus perceraian sebanyak 429.362 kasus. Pada tahun 2015 jumlah perceraian sebanyak 455.044 kasus. Pada tahun berikutnya atau tahun 2016, perceraian di Indonesia turun menjadi 436.957 kasus. Namun angka perceraian kembali naik sebanyak $10 \%$ menjadi 472.780 kasus. Hingga pada tahun 2018 perceraian di Indonesia sebanyak 588.266 kasus perceraian.

Perceraian di Indonesia didominasi oleh cerai gugat atau cerai yang diajukan oleh pihak istri. Pada tahun 2010, cerai gugat di Indonesia sebanyak 169.673 kasus. Tahun berikutnya yaitu pada tahun 2011 sebanyak 191.013 kasus. Pada tahun 2012 terdapat 212.595 kasus. Pada tahun 2013 terdapat 250.360 kasus. Hingga pada tahun 2014, terdapat 268.381 kasus. Pada tahun 2015 sebanyak 253.900 kasus. Tahun berikutnya yaitu pada tahun 2016 terdapat 263.700 kasus. Pada tahun 2017 angka gugat ceraia sebanyak 276.700. pada tahun 2018 sebanyak 307.800. hingga akhirnya pada tahun 2019 sebanyak 355.800 kasus. Angka perceraian dan juga cerai gugat di Indonesia setiap tahunnya selalu meningkat. Bahkan perbandingan cerai gugat (diajukan oleh istri) berbanding dengan cerai talak (diajukan oleh suami) sebanyak 70:30.

Perceraian yang terjadi di Purwodadi pada tahun 2018 sebanyak 2344 kasus. Paling banyak terjadi adalah cerai gugat karena masalah perekonomian [4]. Sedangkan pada tahun 2018 di Pengadilan Agama Kediri, dari 4147 kasus perceraian terdapat 3210 kasus cerai gugat. Hal yang menyebabkan tingginya cerai gugat adalah karena ekonomi, moral, adanya pihak ketiga, dan tidak adanya tanggung jawab [5] Fakta diatas menunjukkan kasus cerai gugat banyak disebabkan karena ekonomi, komunikasi yang buruk, adanya orang ketiga atau perselingkuhan, serta sosial dan budaya. Fokus penelitian di dasarkan pada masalah tersebut sangat menarik untuk di teliti.

\section{METODE}

Penelitian ini menggunakan metode kualitatif deskriptif dengan teknik pengumpulan data berdasarkan studi literatur dan wawancara mendalam dengan 5 orang perempuan berstatus janda yang sudah melalui proses perceraian. Pemilihan jurnal berbatas tahun terbit. Jurnal yang dipilih adalah jurnal terbitan tahun 2010-2020. Pencarian jurnal menggunakan mesin pencarian (google scholar dan Elsevier). Kebaruan topik dalam penelitian ini bersifat komprehensif, maka pencarian literatur termasuk di dalamnya presentasi 
konferensi, tesis magister dan sumber penelitian disertasi doktor [6]. Total jurnal yang menjadi referensi adalah sebanyak 20 jurnal. Pemilihan jurnal berdasarkan pembacaan abstrak. Jika berhubungan dengan tema dari penelitian yang dilakukan, maka tahap berikutnya adalah pembacaan teks jurnal secara menyeluruh [7].

Terdapat 12 jurnal terbitan jurnal nasional dan 8 jurnal terbitan jurnal internasional. Metode penelitian pada jurnal referensi menggunakan metode kualitatif, kuantitatif, dan campuran. Lokasi penelitian dari setiap jurnal mencakup wilayah Indonesia seperti Jawa, Sumatera, Jayapura, dan Kalimantan. Serta wilayah luar negeri seperti Amerika Serikat, Afrika Selatan, Denmark, Swedia, China, Bangladesh, dan Turki.

Karakteristik kehidupan rumah tangga dengan permasalahan dari segi ekonomi ditunjukan oleh responden BD, KS, dan SAL. Karakteristik rumah tangga dengan permasalahan komunikasi yang buruk ditunjukan oleh responden dengan inisial BD dan RS. Karakteristik rumah tangga dengan permasalahan orang ketiga atau perselingkuhan, ditunjukan oleh narasumber dengan inisial KS, RS, JA, dan BD. Karakteristik rumah tangga dengan masalah sosial dan budaya ditunjukan oleh narasumber dengan inisial JA dan SAL.

\section{HASIL DAN PEMBAHASAN}

\section{Faktor Bercerai Karena Ekonomi}

Penyebab perceraian karena ekonomi tidak saja karena kondisi ekonomi yang di bawah rata-rata, namun karena gaya hidup yang hedonis. Hal ini terjadi di Kabupaten Kuningan [8]. Banyak istri yang menggugat cerai suaminya karena suami tidak dapat memenuhi keinginan istrinya. Selain itu, para istri menggugat cerai suami karena suami memiliki hutang. Sebelumnya, pasangan dalam rumah tangga ini merintis usaha dan meminjam uang untuk mengembangkan usahanya. Namun, lambat laun usaha tersebut tidak berkembang dan menyebabkan tidak kembalinya modal dan menumpuknya hutang.

Faktor bercerai karena ekonomi juga diperkuat dengan hasil wawancara. BD, KS, dan SAL. Pernyataan bahwa BD memiliki permasalahan ekonomi adalah:

"yang bikin saya kesel itu kebutuhan rumah belum tercukupi tapi dia (mantan suami) sudah memenuhi hasrat hobinya"

Dalam pernyataan BD mengakui bahwa keadaan ekonominya terganggu karena kebutuhan rumah tangga belum terpenuhi, namun sang mantan suami sudah mengalokasikan keuangan keluarga untuk membeli apa yang menjadi hobinya.

Pernyataan dari narasumber KS tentang keadaan perekonomian keluarga yang menjadi penyebab bercerai adalah sebagai berikut:

"Suami saya dulu pekerjaannya bagus,
tapi semenjak ada masalah sama
kantornya dan dia dipecat, disitu mulai
ga stabil tuh (keadaan ekonominya).
Terus saya bantu dia kan, nyambi apa
nyambi apa. Alhamdulillah sekarang
ada pekerjaan yang lumayan lah
(gajinya). Terus karena keadaan rumah
sudah stabil, dianya (suami) jadi suka
males-malesan. Maksud saya biarpun
saya kerja, dia juga kerja dong
harusnya. Kan kepala keluarganya
dia.".

Narasumber KS mengakui bahwa keadaan ekonomi rumah tangganya pada dahulu kala sempat berada di atas rata-rata, namun semenjak mantan suami mengalami pemecatan, keadaan ekonomi rumah tangga mulai tidak stabil. Pada akhirnya KS memutuskan untuk mencari kerja guna menaikan perekonomian keluarga Setelah keadaan perekonomian membaik, mantan suami KS justru mencari pekerjaan tidak sekuat seperti dahulu.

Hal yang serupa juga dinyatakan oleh SAL, pernyataannya sebagai berikut:

"yaa saya udah ga tahan aja mba. Sama kondisi yang kaya gini, ga berubah. Dulu pernah ngerasain jaya (kondisi ekonomi baik). Tapi ya ga bertahan lama. Pas pacaran mah dia (suami) ga kaya kemaren tuh (sebelum bercerai). Udahnya aja, saya ngerasa capek sendiri."

SAL mengakui, bahwa keadaan perekonomian yang tidak mengalami perubahan dari awal menikah hingga akhirnya bercerai, membuat SAL akhirnya memutuskan untuk bercerai. 


\section{Faktor Bercerai Karena Komunikasi Yang Buruk}

Faktor bercerai karena komunikasi yang buruk juga diperkuat dengan pernyataan dari narasumber. Sebanyak 2 narasumber menyatakan bahwa rumah tangga mereka berakhir karena faktor komunikasi yang buruk. Dalam pernyataan BD yang mengakui bahwa rumah tangganya memiliki komunikasi yang buruk adalah:

"Puncaknya yang bikin saya kesel, kejadian kaya gini ga sekali dua kali. Tapi udah sering. Saya mah gak akan larang mbak, toh dia juga pernah ko saya biarin (membeli apa yang suaminya inginkan), asal buat rumah sama anak tercukupi. Keselnya saya sama dia awalnya bisa tuh (disampaikan). Tapi makin lama makin ngelunjak, sering ngulangin lagi."

Pernyataan BD menjelaskan bahwa BD memiliki perasaan kesal dengan mantan suaminya, hal itu dikarenakan mantan suami tidak bijak dalam mengalokasikan keuangan rumah tangga sehingga, keadaan ekonomi rumah tangga menjadi tidak stabil. Perasaan kesal yang tidak disampaikan kepada mantan suami, lalu kebiasaan mantan suami mengulang kesalahan yang sama membuat BD memendam perasaan tersebut. Lalu pada akhirnya BD tidak dapat membendung kembali perasaannya menyebabkan perceraian di rumah tangga.

Dalam pernyataan narasumber RS, juga menyatakan bahwa komunikasi yang buruk menyebabkan rumah tangganya bercerai. Pertanyaannya adalah sebagai berikut:

\footnotetext{
"kadang kalo ada apa-apa yang saya rasakan, saya suka ga bilang. Bukannya gamau, tapi gak bisa buat ngomongnya. Ditambah dia (suami) kadang suka ga perhatian. Dia maunya apa, menurut dia saya ga ngerti. Padahal saya selalu berusaha ngertiin dia."
}

Narasumber RS menyatakan bahwa RS sulit untuk menyampaikan perasaan. Hal ini diperparah dengan sikap suami yang tidak peka dengan keadaan. RS juga kerap merasakan bahwa mantan suaminya menilai dirinya tidak memahami mantan suami, padahal menurut RS ia sudah berusaha untuk mengerti apa yang menjadi keinginan mantan suaminya.

\section{Faktor Adanya Orang Ketiga Atau Perselingkuhan}

Berkomunikasi dengan niat awal tidak serius, tidak jarang berlanjut hingga akhirnya terjadi proses pertemuan. Pertemuan ini terjadi tanpa sepengetahuan pasangan yang lainnya, dan ketika salah satu pasangan mengetahui bahwa pasangannya bertemu dengan seseorang yang diajaknya berkomunikasi lewat pesan teks, individu ini merasa dirinya dibohongi dan menganggap bahwa pasangannya sudah melakukan perselingkuhan.

Hal ini pula yang terjadi pada 4 narasumber. Keempat narasumber mengakui adanya orang ketiga dalam rumah tangga mereka, hingga akhirnya sering terjadi perdebatan panjang yang tidak berkesudahan. Saat terus menerus narasumber dan pasangannya bertengkar dan tidak menemukan solusi, mereka akhirnya memutuskan untuk bercerai.

Faktor ini juga didukung oleh narasumber. Pernyataan narasumber KS adalah sebagai berikut:

"Di tambah ya ada orang lain gitu deh, jadi saya yaudah udahin aja (bercerai). Toh anak-anak sama saya juga insya Allah mah bisa

hidup."

"Saya ga munafik ya mbak, Namanya kebutuhan hidup kita kadang ada yang bisa Menuhin, walaupun ya saya mampu. Ditambah saya juga butuh perhatian, dan saya dapatkan itu dari orang lain. Ya mau gimana, kalo sama suami sendiri aja saya sengsara. Kadang teringat juga sama anak, tapi alhamdulillah yang sekarang (suami baru) juga peduli sama anak-anak. Semoga awet si ya (pernikahannya)"

Pernyataan KS menjelaskan bahwa ia mengakui adanya orang ketiga dalam rumah tangganya. Orang ketiga ini diakui KS mampu membahagiakan KS secara batin. Keadaan rumah tangga yang kerap kali bertengkar dan KS menemukan orang lain dalam rumah tangganya yang lebih mampu membuat KS bahagia secara batin, membuat KS memutuskan untuk bercerai dengan suaminya.

Pernyataan narasumber RS juga menjelaskan bahwa salah satu alasan RS bercerai dengan suaminya adalah karena orang ketiga atau perselingkuhan. Berikut pernyataan RS: 
"Ya Allah isinya bikin saya sakit hati, chatnya pakai sayang-sayangan, terus mereka kaya janjian. Suka kirim-kirim foto."

"abis itu besoknya saya omongin, saya tanya baik-baik, itu siapa. Dia (mantan suami) malah marah-marah, bilang saya ga sopan buka-buka hp dia, terus katanya bukan urusan saya juga buat tau. Yaudah abis itu jadi ngejauh dianya, saya juga masih sakit hati."

RS menemukan pesan singkat dalam ponsel mantan suaminya, bahwa pasangannya itu berkirim pesan yang bernadakan romantis, setelah dibicarakan baikbaik, justru mantan suaminya saat itu marah dengan RS dan menganggap RS tidak sopan karena telah menerobos privasinya. Kejadian ini membuat RS menyimpulkan bahwa mantan suaminya memiliki wanita idaman lain.

Narasumber JA juga menyatakan bahwa rumah tangganya kandas karena adanya orang ketiga. Berikut pernyataan JA:

"Saya taunya waktu itu dia (mantan suami) ngaku ke saya, soalnya perempuannya (selingkuhan) hamil, terus minta tanggung jawab. Saya gamau mba di madu. Ya suruh dia pilih, dia gabisa kasih kepastian. Yaudah saya aja udahin semuanya (bercerai) asal ya urusan anak dia tetap tanggung jawab."

Perselingkuhan dalam rumah tangga JA yang dilakukan oleh mantan suaminya berawal dari kesibukan JA mengurus anak mereka yang masih kecil. Jarak antar anak yang berdekatan membuat tenaga dan pikiran JA terfokus kepada anakanaknya. Namun, suaminya pada saat itu tidak dapat memahami kondisi tersebut, membuat mantan suaminya mencari wanita lain.

Narasumber BD dalam pernyataannya menyatakan sebagai berikut:

"saya emang tau si perempuannya. Temennya pas masih sekolah terus pernah satu kerjaan. Taunya waktu itu pernah liat mereka mention-mentionnya di Instagram. Saya cemburu lah ya, di bilang temen masa iya sesering itu (berbalas komentar) terus isinya kaya ga punya istri (chat romantis). Saya gak bisa digituin, saya cemburu lah ya"
Dalam pernyataanya BD mengakui bahwa ia cemburu dengan perempuan yang kerap berbalas komentar di media sosial, menurut BD intensitasnya cukup sering. Hal ini yang membuat BD merasa cemburu dan menganggap suaminya memiliki wanita idaman lain.

\section{Faktor Sosial dan Budaya}

Hal yang sama juga dinyatakan oleh narasumber. Sebanyak 2 narasumbernya mengakui bahwa adanya perbedaan sosial dan budaya yang menyebabkan rumah tangga mereka bercerai.

Pernyataan JA memperkuat bahwa faktor sosial dan budaya menjadi salah satu alasan perceraian. Berikut pernyataannya:

"Saya dari awal suka ngerasa aneh aja sama keluarganya (mantan suami). Dulu (sebelum menikah) kalo ketemu mamah (ibu mertua) suka gabisa jadi diri sendiri. Suka diomongin juga. Mamah (ibu mertua) sering bilang, jadi perempuan harus mandiri, tapi dia melarang saya kerja. Makanya sekarang saya ga kerja. Kata dia mah perempuan kalo kerja ga bisa jaga harga dan martabat suami. Saya iya-iya aja, namanya sama calon mertua ya. Gataunya sampai saya nikah udah lama gini juga kadang suka ga masuk aja ajaran keluarganya dia (mantan suami). Ngerasa ganjel, tapi ya saya syukurin aja awalnya. Tapi lama-lama gak bisa."

JA mengakui bahwa ia merasa tidak nyaman dengan konsep pemikiran yang menjadi panduan hidup dari ibu mertuanya. Perbedaan konsep pemikiran ini yang akhirnya membuat JA memutuskan untuk mengakhiri rumah tangganya.

Pernyataan oleh SAL juga membuktikan bahwa faktor sosial dan budaya menyebabkan perceraian. Berikut pernyataan SAL:

"saya dari dulu dididik sama ibu bapak saya, buat mandiri dan tanggung jawab. Tapi mantan saya itu orangnya kadang suka ngedown. Dan kalo udah begitu suka merembet kemana mana. Jadi males nyari kerja, malas berusaha. Saya gabisa tuh liat pasangan saya kaya gitu, jadi suka saya semangatin, saya tegur, saya nasihatin. Tapi menurut dia, saya cerewet, banyak nuntut. Ya namanya 
rumah tangga ya, butuh perjuangan buat ngadepin setiap masalah yang dateng. Dan yaudah mba, ditambah ibunya juga kadang suka manjain dan belain dia. Saya ga tahan lama-lama."

Perbedaan konsep dan sikap dalam setiap menghadapi masalah, menyebabkan SAL kerap merasa tidak cocok dengan suaminya pada saat itu. Hal ini yang menyebabkan SAL memutuskan untuk bercerai dengan pasangannya.

\section{Faktor Bercerai Karena Ekonomi}

Sebanyak $45 \%$ jurnal menyatakan bahwa faktor ekonomi menjadi salah satu penyebab perceraian. Faktor ekonomi ini bermula dari berbagai macam masalah, seperti suami yang tidak dapat memenuhi kebutuhan rumah tangga karena tidak adanya pekerjaan tetap atau suami malas bekerja sehingga pemasukan keluarga menjadi tidak jelas dari mana [9] yang berdampak pada berkurangnya pemenuhan kebutuhan keluarga. Bagi istri ini tidak sesuai dengan harapan dari pernikahan yang dilakukan untuk memperoleh keuntungan karena memiliki suami yang bekerja. Permasalahn ekonomi juga hadir dari keluarga dengan pasangan yang bekerja sebagai aparatur sipil negara (ASN). ASN yang digadang-gadang sebagai pekerjaan yang stabil secara keuangan, namun banyak terjadi pada para pegawai di Rokan Hilir Provinsi Riau. Para ASN yang bercerai karena ekonomi, memiliki masalah dengan gaya hidup yang tinggi, sehingga penghasilan yang didapat selalu terasa tidak cukup [10]

Meskipun bukan menjadi urutan pertama alasan perceraian, di Lebowakgomo faktor ekonomi berada pada urutan ke empat. Riset menunjukan bahwa tekanan keuangan berdampak langsung pada kesejahteraan finansial [11]. Semakin tinggi tekanan keuangan keluarga maka semakin rendah keuntungan yang diharapkan dari pernikahan dan semakin tinggi kemungkinan perceraian [12]. Ketika pasangan tidak dapat mengelola keuangan mereka karena sumber daya yang tidak memadai atau keputusan pengelolaan keuangan yang buruk, mereka dibatasi dari mencapai kesejahteraan keuangan dan kepuasan hubungan [11].

Faktor ekonomi juga mempengaruhi keadaan rumah tangga pada aspek lainnya. Dalam beberapa kasus, faktor ekonomi merembet dengan kasus perselingkuhan. Dengan ekonomi yang buruk, kepala keluarga kerap bertengkar dengan istrinya. Pertengkaran ini menyebabkan suami mencari wanita lain. Tidak jauh berbeda dengan sikap suami yang mencari wanita lain karena kerap bertengkar dengan istrinya, pihak istri pun juga mencari pria dengan segi ekonomi yang lebih baik guna menunjang kebutuhan hidup yang tidak dapat dipenuhi oleh suaminya. Dari faktor ekonomi ini, konflik dalam keluarga dapat berkembang menjadi banyak konflik yang lainnya [13].

Faktor ekonomi juga disebabkan karena pernikahan dini [14]. Banyak anak muda yang termasuk ke dalam golongan remaja akhir, memutuskan untuk menikah muda. Pernikahan dini ini terjadi selain karena budaya, adalah karena para remaja ini tidak memiliki tujuan hidup serta tidak tahu harus melakukan apa selepas tamat SD (Sekolah Dasar). Akhirnya, para remaja ini memutuskan untuk menikah dini. Rata-rata pernikahan dini terjadi dengan kondisi masing-masing individu belum siap secara mental dan finansial. Sehingga, banyak dari mereka yang tidak tahu bagaimana harus bertahan hidup yang salah satunya adalah memiliki penghasilan untuk memenuhi kebutuhan rumah tangga. Ketidakmampuan memenuhi kebutuhan rumah tangga pada pasangan ini, menjadi pemicu terjadinya perceraian.

Keadaan ekonomi yang buruk pada akhirnya juga mempengaruhi kehidupan rumah tangga yang lain. Beberapa pasangan mengaku mengalami traumatik berumah tangga, karna kerap mendapatkan perlakuan suami yang buruk. Perlakuan ini terjadi karena suami kerap berjudi untuk mendapatkan uang [15]. Kebiasaan berjudi ini diringi dengan minum minuman keras. Kekerasan dalam rumah tangga pun kerap terjadi karena kondisi kesadaran suami yang dalam pengaruh minuman keras.

\section{Faktor Bercerai Karena Komunikasi Yang Buruk}

Sebanyak 35\% jurnal menyatakan faktor penyebab perceraian adalah karena komunikasi yang buruk. Terdapat fakta bahwasannya komunikasi yang buruk menciptakan masalah yang lebih luas, seperti: salah satu pasangan tidak merasa dihargai, salah satu pasangan tidak bisa diajak berbagi, salah satu pasangan tidak ada saat dibutuhkan [16] Komunikasi yang buruk juga disebabkan karena jarak tempat tinggal antar pasangan. Hal ini berlaku pada pasangan yang salah satunya bekerja di luar negeri. Tingginya perceraian ini sebab utamanya adalah masalah komunikasi antara TKI dengan pasangannya tidak dilakukan secara konsisten [17]. Terdapat 3.520 kasus perceraian yang terjadi di Purwodadi disebabkan karena adanya 
ketidakharmonisan dalam keluarga sebab dari komunikasi yang buruk [18]. Pada dasarnya buruknya hubungan interpersonal antara suami dan istri ini bukan menjadi hal utama dalam pasangan memilih untuk mengakhiri rumah tangga. Buruknya komunikasi antar pasangan berawal dari ketidakmampuan menyampaikan perasaan yang dirasakan diri sendiri kepada pasangan. Hal ini akan menyebabkan konflik yang lebih kompleks.

Komunikasi interpersonal yang kurang baik antar pasangan ini disebabkan karena hilangnya rasa percaya terhadap pasangan. Salah satu pasangan merasa dikhianati dengan adanya perselingkuhan. Ketika perselingkuhan ini terjadi, salah satu pasangan menjadi berkurang kepercayaan bahkan hingga hilang rasa percaya dan akhirnya berdampak kepada komunikasi yang semakin buruk yang menyebabkan perceraian

Terjadinya bisnis dalam rumah tangga yang giat dengan peningkatan hutang juga dengan peningkatan penjualan, pada akhirnya memicu adanya setres. Kondisi pasangan harus professional dalam pekerjaan dan juga pada kehidupan seharihari anggota dari bisnisnya merupakan keluarganya sendiri. Tuntutan akan penaikan omzet penjualan mempengaruhi setres dalam keluarga dan meningkatkan perceraian [19].

Stres juga dapat memicu terjadinya perceraian, di Bangladesh banyak pasangan bercerai efek dari tidak tersampaikannya perasaan yang dialami kepada pasangannya [20]. Komunikasi yang buruk adalah dampak dari ketidakmampuan seorang istri menyampaikan perasaannya. Bermula dari merasa hubungan rumah tangga diganggu oleh mertua, mendapat perlakuan buruk dari salah satu pihak keluarga (pihak suami), dan adanya tuntutan dari keluarga pasangannya (pihak suami). Hal ini yang membuat salah satu pasangan merasa stres namun tidak dapat menyampaikan kepada pasangannya. Saat memiliki kesempatan untuk menyampaikan apa yang dirasa, ternyata pasangannya sendiri cenderung menyalahkan karena tidak mampu beradaptasi.

Komunikasi yang buruk juga terjadi saat pasangan memiliki anak. Sebuah riset studi di Swedia membuktikan bahwasannya terdapat pasangan yang menikah selama 8 tahun tanpa anak lebih bahagia daripada saat mereka memiliki anak [21]. Pasangan yang telah menikah dan memiliki anak, mengalami penurunan keintiman selama 4 tahun pertama, dan bisa merasakan keintiman kembali setelah tahun berikutnya namun tidak sama seperti saat dahulu sebelum memiliki anak. Hal ini terjadi karena, salah satu pasangan atau keduanya merasakan mereka sudah tidak intim kembali, memiliki perbedaan dalam kesukaan dan kepribadian, tidak adanya komitmen, dan keadaan stres yang melanda [22].

Para pasangan yang menikah dan memiliki anak ini merasa bahwa pasangan mereka tidak membantu secara dukungan sosial dalam mendidik dan merawat anak mereka. Oleh sebab itu, banyak perceraian terjadi di Swedia saat anak-anak mereka berusia 1-4 tahun. Dalam kasus ini dapat dilihat, bagaimana dibutuhkannya komunikasi yang baik untuk mendidik anak, agar tujuan rumah tangga dapat dicapai bersama tanpa menjadikan anak sebagai alasan untuk bercerai. Komunikasi yang buruk memperparah keadaan rumah tangga saat apa yang terjadi dalam diri individu pasangan menikah sedang dirasakan namun tidak dapat disampaikan kepada pasangannya. Kemampuan yang minim dalam bersinergi mendidik dan membesarkan anak, akhirnya mengurangi keintiman antar pasangan, minim dukungan sosial, dan rendah dalam berkomitmen.

Buruknya komunikasi dalam rumah tangga, dapat memicu ketidakharmonisan. Ketidakharmonisan ini karena antar pasangan tidak mampu menyampaikan dan menyelaraskan tujuan perkawinan, sehingga sering terjadi perdebatan atau pertengkaran terus menerus [23]. Faktor ketidakharmonisan di dalam keluarga ini disebabkan oleh adanya pergeseran nilai perkawinan. Pasangan suami dan istri kurang memahami makna dari tujuan pernikahan dan berkeluarga yang menjadi salah satu nilai dalam ketahanan keluarga [24].

\section{Faktor Adanya Orang Ketiga Atau Perselingkuhan}

Sebanyak 35\% jurnal menyatakan salah satu faktor penyebab perceraian adalah karena perselingkuhan. Perselingkuhan yang terjadi pun beragam, sekedar melakukan pesan teks secara daring hingga ke perilaku zina yaitu berhubungan badan. Salah satu kasus yang terjadi di Surabaya, terdapat pasangan dalam kasus ini adalah suami, yang kerap berselingkuh dan bergonta-ganti wanita. Karakter ini yang tidak disukai oleh istri, hingga akhirnya sang istri menggugat cerai suaminya [25]. Hasil penelitian di Banyuwangi, diketahui faktor yang menyebabkan pasangan suami istri memiliki wanita ataupun pria idaman lain disebabkan karena kondisi ekonomi yang kurang dan rendahnya pemahaman tentang hak dan kewajiban sebagai seorang suami ataupun istri [13]. 
Perceraian yang disebabkan karena cemburu ketika salah satu pasangan memergoki pasangannya tengah berkomunikasi lewat pesan teks juga terjadi di Amerika Serikat [26]. Meskipun salah satu pasangan ini ketika berkomunikasi dengan orang lain ataupun lawan jenis di media sosial tidak berniat untuk serius dan hanya sekedar melepas penat atas pertengkaran dengan pasangannya di rumah [27]. Perceraian di Kota Pariaman, juga terjadi karena perselingkuha. Perselingkuhan ini bermula dari adanya ketidakharmonisan dalam rumah tangga, sehingga salah satu pasangan mencari ketenangan dengan orang lain. Namun terdapat pula pasangan yang melakukan perselingkuhan terlebih dahulu, hingga dampak dari perselingkuhan ini adalah seringnya terjadi ketidakharmonisan dalam rumah tangga [28]

\section{Faktor Sosial dan Budaya}

Sosial dan budaya dapat mempengaruhi perceraian. Sebanyak 35\% jurnal, membahas bagaimana sosial dan budaya berperan dalam perceraian. Salah satunya karena pernikahan beda suku di Indonesia. Terdapat benturan dan kendala yang berupa komunikasi. Pasangan berbeda suku ini mengalami rintangan perbedaan kerangka berpikir, perbedaan persepsi, perbedaan bahasa, hingga kesalahpahaman dari komunikasi nonverbal. Kesalahan nonverbal terjadi karena adanya perbedaan budaya. Lalu perbedaan budaya ini merujuk pada terjadinya sumber konflik dalm konteks hubungan interpersonal pasangan beretnis Jawa-Papua/ konflik ini terjadi baik dari ketegori keluarga harmonis maupun dari pasangan yang sudah bercerai [29]. Dalam kasus ini, etnis Jawa yang kerap memperhatikan tatanan bahasa serta nada berbicara, kerap memiliki masalah dengan etnis Papua yang tidak terlalu memikirkan tatanan bahasa dan nada bicara. Selain itu, ada pasangan yang berasal dari etnis Jawa merasa kerap direndahkan oleh pasangannya yang beretnis Papua. Hal-hal ini yang memicu adanya perceraian pada pasangan dengan etnis Jawa-Papua.

Perceraian juga terjadi dengan bantuan pihak ketiga. Pihak yang membantu perceraian ini di Desa Cangkringan Kabupaten Indramayu [14]. Lebe adalah pembantu pegawai pencatat nikah menjadi fasilitator dalam perceraian yang diajukan warga Desa Cangkringan. Lebe akan mencatat administrasi warga yang bercerai tanpa datang ke pengadilan agama. Para pasangan yang ingin bercerai namun tidak pergi ke pengadilan agama ini sebabnya adalah letak rumah mereka yang jauh dari pengadilan agama, keadaan ekonomi sehingga tidak mampu pergi ke pengadilan agama. Cerai Lebe disediakan dengan maksud untuk menertibkan perceraian yang belum sah secara negara, masyarakat diberi kemudahan Cerai Lebe karena peraturan untuk bercerai dalam cerai lebe tidak serumit proses perceraian di Pengadilan Agama. Masyarakat yang ingin bercerai ini, kerap kali terbentur dengan hukum negara.

Kondisinya pasangan tersebut sudah cerai secara agama karena sudah jatuh talak, namun menurut negara pasangan tersebut belum cerai dan menyarankan agar melakukan proses mediasi. Perceraian di daerah ini terjadi karena banyak pria yang beranggapan bahwa biaya mahar lebih murah daripada biaya rujuk. Banyak laki-laki yang sudah menikah lalu pergi ke daerah lain dan mengaku bahwa diri sudah meninggalkan istri, lalu pria ini menikah dengan perempuan lain dengan mahar yang murah. Meskipun mahar yang mahal atau murah bukan menjadi ketentuan seseorang untuk menikah, namun mahar yang murah membuat seseorang mudah untuk kawin dan cerai.

Pasangan di Banjarmasin, mengalami peningkatan perceraian pasca gencarnya korban Kekerasan Dalam Rumah Tangga/KDRT melaporkan tindakan kekerasan kepada Lembaga Bantuan Hukum/LBH [30]. Banyak perempuan atau pihak istri mengaku mengalami KDRT, namun mereka memilih bungkam. Hal ini disebabkan karena para istri khawatir ketika melaporkan tindak KDRT tersebut, justru keadaaan semakin parah. Namun, seiring dengan berjalannya waktu dan semakin banyak LBH yang mampu menaungi korban KDRT, semakin banyak pula pihak korban yang berani untuk bersuara. Perceraian juga dapat terjadi karena perbuatan pemabuk, pemandat, dan penjudi dari salah satu pasangan. Perilaku ini hadir karena adanya krisis agama dan faktor lingkungan. Sehingga salah satu pasangan yang tidak tahan dengan perilaku pasangannya ini, menggugat cerai. Kasus ini terjadi di kota Karawang [31]. Selain itu pengalaman hidup pada pasangan di Turki mengakibatkan banyak rumah tangga yang memutuskan untuk bercerai [32]. Hal ini terjadi karena salah satu pasangan yang didominasi oleh istri pernah mengenyam pendidikan yang tinggi dan memiliki pengalaman hidup di luar kota Pengalaman hidup dan mengenyam pendidikan yang tinggi, menjadi tolak ukur bagi pihak istri untuk menjadi pengalaman tersebut dalam membangun rumah tangga. Pada kenyataanya, mereka kerap terbentur dengan fakta bahwa kehidupan rumah 
tangga mereka tidak lebih baik dengan pengalaman mereka sebelumnya.

\section{Pendidikan Pranikah oleh Kantor Urusan Agama (KUA)}

Pembekalan pranikah oleh kantor urusan agama menjadi salah satu proses sebelum pasangan di Indonesia ingin menikah. Pembekalan pranikah ini bertujuan untuk memberi gambaran serta persiapan tentang berumah tangga bagi calon pengantin. Hal ini dilakukan untuk menanggulangi angka perceraian yang tinggi. Pendidikan pranikah bukan semata-mata upaya prevensi terhadap kemungkinan gangguan dalam pernikahan yang akan berlangsung, namun juga untuk meningkatkan kualitas hubungan suami-istri yang baik serta memberikan kesejahteraan, rasa aman, rasa kebahagiaan dalam perkawinan [33].

Pendidikan pranikah juga dilakukan oleh narasumber dalam penelitian ini. Namun sayangnya, Pendidikan pranikah tidak dimaknai secara mendalam oleh masing-masing individu. Hasil wawancara dengan kelima narasumber dapat ditarik kesimpulan bahwa pendidikan pranikah bagi para narasumber hanya sebatas proses formalitas menuju proses pernikahan. Meskipun mereka merasa antusias pada awalnya, namun seiring berjalannya waktu para narasumber mengaku tidak begitu memaknai pendidikan pranikah mereka. Sehingga, hal-hal yang buruk mudah menggoyahkan rumah tangga mereka sampai mereka memutuskan untuk bercerai.

\section{KESIMPULAN}

Penyebab perceraian rentang sepuluh tahun di Indonesia semakin beragam. Meskipun, saat bersidang untuk bercerai alasan-alasan sesuai dengan apa yang telah dituliskan oleh undangundang, namun faktor pemicu yang melandasi sebuah rumah tangga memutuskan untuk bercerai juga semakin beragam. Faktor perceraian tidak hanya berasal dari satu sektor. Ada banyak sektor yang akhirnya memperparah keadaan rumah tangga hingga akhirnya memutuskan untuk bercerai. Faktor sosial dan budaya semakin beragam hadir di kehidupan saat ini, berdampak terhadap tingginya perceraian. Kesadaran akan keadaan semakin membuat para pasangan dalam rumah tangga mampu mengambil sikap atas apa yang terjadi dalam pernikahannya. Pendidikan pranikah hadir bukan semata untuk menjadi sebuah proses menuju pernikahan. Namun sayangnya, banyak pihak yang memaknai pendidikan pranikah sebatas formalitas saja. Hingga akhirnya pada saat rumah tangga mereka menemukan masalah, para pihak tersebut tidak mampu menanggulanginya dan berujung dengan perceraian.

\section{UCAPAN TERIMA KASIH}

Terimakasih kepada seluruh dosen Pendidikan Kesejahteraan Keluarga, Universitas Negeri Jakarta yang telah memberikan ilmunya yang sangat bermanfaat serta dedikasi terbaik mendidik mahasiswa untuk pendidikan Indonesia yang lebih baik.

\section{REFERENSI}

[1] A. Matondang, "Faktor-faktor yang Mengakibatkan Perceraian dalam Perkawinan," vol. 2, no. 2, pp. 141-150, 2014.

[2] Suryadi, A. Zakso, and Rustiyarso, "Analisis Interaksi Sosial Asosiatif Pimpinan Dengan Karyawan Dalam Memotivasi Kerja Di Hotel Dangau Kabupaten Kubu Raya," J. Pendidik. dan Pembelajaran Khatulistiwa, vol. 5, no. 11, pp. 1-13, 2016.

[3] A. S. Muhid, "Akomodasi dalam Konflik Sosial pada Diplomasi Pemberian Pisuke Lintas Desa : Kajian Sosioliguistik," Humanit. Jounal Lang. Lit., vol. 5, no. 2, pp. 163-170, 2019.

[4] P. S. A. Asy-syakhshiyah et al., "FAKTOR EKONOMI PENYEBAB CERAI GUGAT ( Studi Kasus di Pengadilan Agama Purwodadi Tahun 2018 )," no. 9, pp. 29-44, 2020.

[5] R. A. Wahab, Abdillah. Zahara, "Analisis Yuridis Terhadap Faktor-Faktor Penyebab Tingginya Tingkat Cerai Gugat di Pengadilan Agama Kabupaten Kediri," J. Huk. Kel. Islam, vol. 3, no. Desember, pp. 59-78, 2020.

[6] D. Moher et al., "Preferred reporting items for systematic review and meta-analysis protocols (prisma-p) 2015 statement," Japanese Pharmacol. Ther., vol. 4, no. 1, pp. 1-9, 2015.

[7] C. A. Kildare and W. Middlemiss, "Impact of parents mobile device use on parent-child interaction: A literature review," Comput. Human Behav., vol. 75, pp. 579-593, 2017.

[8] S. Muhammad, "The phenomenon of Contested Divorced in Kuningan District: A Study of Social Change in Society and Family Fenomena Cerai Gugat di Kabupaten Kuningan: Sebuah Kajian Perubahan Sosial dalam Masyarakat dan Keluarga," J. Bimas Islam, vol. 9, pp. 599-640, 2016. 
[9] B. Siburian, "Analisis Faktor-Faktor Penyebab Perceraian Berdasarkan Keputusan Pengadilan Negeri Balige Tahun 2017," vol. 1, no. 1, pp. 31-39, 2019.

[10] E. Suryani, "Tingkat Perceraian Muslim dan Non muslim Di Indonesia," Mizan J. Islam. Law, vol. 3, no. 2, pp. 153-200, 2018.

[11] N. E. Mohlatlole, S. Sithole, and M. L. Shirindi, "Factors Contributing to Divorce Among Young Couples in Lebowokgomo," Aggress. Violent Behav., vol. 54, no. 8, pp. 256-274, 2017.

[12] S. Doriza, Ekonomi Keluarga, Pertama. Bandung: PT Remaja Rosdakarya, 2015.

[13] H. Harjianto and R. Jannah, "Identifikasi Faktor Penyebab Perceraian Sebagai Dasar Konsep Pendidikan Pranikah di Kabupaten Banyuwangi," J. Ilm. Univ. Batanghari Jambi, vol. 19, no. 1, p. 35, 2019.

[14] W. Nuroniyah, "Cerai Lebe sebagai Inisiatif Lokal dalam Upaya Meminimalisir Praktek Perceraian Liar (Studi Kasus di Desa Cangkring Kabupaten Indramayu)," vol. 14, no. 1, pp. 113-130, 2020.

[15] I. Garwan, A. Kholiq, and M. G. G. Akbar, "Tingkat Perceraian Dan Pengaruh Faktor Ekonomi Di Kabupaten Karawang," J. Ilm. Huk. De'Jure Kaji. Ilm. Huk. , vol. 3, no. 1, 2018.

[16] A. Sari, Taufik, and A. Sano, "Kondisi Kehidupan Rumah Tangga Pasangan Sebelum Bercerai dan Faktor-Faktor Penyebab Terjadinya Perceraian (Studi pada Masyarakat Suku Jawa di Kecamatan Sei Dadap Kota Kisaran)," J. Konseling dan Pendidik., vol. 4, no. 3, pp. 41-51, 2016.

[17] U. S. Winataputra, "Jurnal moral kemasyarakatan vol. 1, no.1, juni 2016," $J$. Moral Kemasyarakatan, vol. 1, no. 1, pp. 1536, 2016.

[18] M. H. Nuriyyatiningrum, "Tinjauan Yuridis Terhadap Faktor Penyebab Perceraian di Pengadilan Agama Purwodadi," J. Lentera Kaji. Keagamaan, Keilmuan, dan Teknol., vol. 18, no. 2, pp. 126-138, 2019.

[19] P. Sanchez-Ruiz, I. Maldonado-Bautista, and M. Rutherford, "Business stressors, familybusiness identity, and divorce in family business: A vulnerability-stress-adaptation (VSA) model," J. Fam. Bus. Strateg., vol. 9, no. 3, pp. 167-179, 2018.

[20] M. Akter and R. Begum, "Factors for Divorce of Women Undergoing Divorce in Bangladesh," J. Divorce Remarriage, vol. 53, no. 8, pp. 639-651, 2012.
[21] M. Hansson and T. Ahlborg, "Factors contributing to separation/divorce in parents of small children in Sweden," Nord. Psychol., vol. 68, no. 1, pp. 40-57, 2016.

[22] G. M. Hald, J. M. Strizzi, A. Ciprić, and S. Sander, "The Divorce Conflict Scale," $J$. Divorce Remarriage, vol. 61, no. 2, pp. 83-104, 2020.

[23] M. Luthfi, "Komunikasi Interpersonal Suami dan Istri Dalam Mencegah Perceraian di Ponorogo," vol. 2, 2017.

[24] R. M. Amalia, M. Y. A. Akbar, and S. Syariful, "Ketahanan Keluarga dan Kontribusinya Bagi Penanggulangan Faktor Terjadinya Perceraian," J. Al-Aazhar Indones. Seri Hum., vol. 4, no. 2, p. 129, 2018.

[25] K. Fajri and Mulyono, "Selingkuh Sebagai Salah Satu Faktor Penyebab Perceraian (Analisis Putusan No. 3958/Pdt.G/2012.PA.Sby. Perspektif Maqashid Syariah,"עלון הנוטע, vol. 66, no. 3958, pp. 3739, 2012.

[26] S. Valenzuela, D. Halpern, and J. E. Katz, "Computers in Human Behavior Social network sites , marriage well-being and divorce : Survey and state-level evidence from the United States," vol. 36, pp. 94-101, 2014.

[27] S. Zheng, Y. Duan, and M. R. Ward, "The effect of broadband internet on divorce in China," Technol. Forecast. Soc. Change, vol. 139, no. May, pp. 99-114, 2019.

[28] Rahmawita and A. A. Putra, "Faktor-Faktor Penyebab Perceraian pada Pengadilan Agama Pariaman dengan Penerapan Metode Regresi Logistik Biner," UNPjoMath, vol. 2, no. 4, pp. 29-33, 2019.

[29] R. Anwar and H. Cangara, "Perkawinan Dan Perceraian Etnis Jawa Dengan Papua Di Kota Jayapura ( Suatu Strategi Manajemen Konflik Dalam Hubungan Interpersonal Pasangan Suami Istri ) The Intercultural Communication Barriers of Marriage and Divorce Between Java and Papua Ethnics in Th," J. Komun. KAREBA, vol. 5, no. 2, pp. 273-285, 2016.

[30] M. Umar, "Marriage and Divorce: How the Two Manifest within the Banjarise Community in Indonesia," J. Soc. Sci. Res., vol. 6, pp. 245 251, 2020.

[31] I. Garwan, A. Kholiq, and M. Gary, "Tingkat Perceraian dan Pengaruh Faktor Ekonomi Di Kabupaten Karawang," J. Ilm. Huk., vol. 3, no. 3, 2018.

[32] K. Caarls and H. A. G. De Valk, "Regional Diffusion of Divorce in Turkey," Eur. J. Popul., vol. 34, no. 4, pp. 609-636, 2018. 
[33] R. Bustan, "Persepsi Dewasa Awal Mengenai

Kursus Pranikah," J. Al-AZHAR Indones. SERI

Hum., vol. 3, no. 1, p. 82, 2017. 